\title{
解説
}

\section{プラズマディスプレイパネルの材料開発 真空成膜材料を中心として}

\author{
望 月 昭 宏
}

（受理1998年 1 月 8 日，掲載決定1998年 4 月 4 日）

Materials Research for Plasma Display Panels

\section{Akihiro MOCHIZUKI}

(Fujitsu Labs Ltd., Display Lab. 64 Nishiwaki, Ohkubo, Akashi 674-8555)

(Received January 8, 1998, Accepted April 4, 1998)

\section{1. はじめに}

フルカラー動画対応可能なプラズマディスプレイパネ ル (PDP) は, 同じフラットパネルディスプレイデバ イスとして製品化が先行した液晶ディスプレイ（LCD） に対し，対角40インチ以上の大面積表示が容易である点 が最も大きな特長である.PDPのこの特長を裏付けて いるのが，その製造方法に扩ける厚膜プロセスの多用で ある、厚膜プロセスとは，一般にスクリーンマスクを用 いた印刷プロセスを意味する，基本的な製造方法が印刷 プロセスであるため, 大面積ディスプレイでも比較的低 コストで効率的な作製が可能となる.

しかし, 現在, 各社で製品化が進められている AC 型 PDP では，真空を利用した成膜プロセスも，厚膜プロ セス同様, 極めて重要となる。本稿では, AC 型 PDP に扣ける真空成膜プロセスの現状と課題, 真空成膜層の 役割と物性の解説を行らことを目的に，AC 型 PDP の 構成, PDP に特有な厚膜材料についても概説を行ら.

\section{2. $\mathrm{AC}$ 型 PDP の構成}

$\mathrm{AC}$ 型 PDP の構造上の特徵は, 放電のための電極が 誘電体に覆われていることにある. 図 1 に, 最も一般的 な面放電方式 AG 型 PDP の構成を示す．放電の原理に

\footnotetext{
* 株式会社 富士通研究所 ペリフェラルシステム研究所 ディスプレ 亿研究部（产674-8555 明石市大久保町西脇64)
}

ついて，他章に譲るが, 図 1 に示す誘電体層が, 表示 デバイスとしての PDP の特性に大きく関わる.

$\mathrm{AC}$ 型 PDP の構成は, 図 1 亿示すと括り極めて単純 で, 放電を維持するための電極, 誘電体, 执上び誘電体 を放電から守る保護層を備えた前面基板と, 赤, 青, 緑 各色蛍光体の発光を区別するためのバリアリブ，および 放電を誘起するための電極を備えた背面基板の組み合わ せである. これらの前面基板，背面基板の間にネオン等 の不活性ガスが封入される. また, PDP 本体とは別に 電磁ノイズ除去, 拉よびュントラスト比向上用の前面フ ィルターが用いられる。

図 1 の構成中，一般に真空プロセスにより成膜される 部分は, 透明電極, バス電極, 保護層, および前面フィ ルター用透明導電層である. その他の誘電体層, バリア リブ層, 蛍光体層, および周辺シール層は, 一般にスク リーン印刷法により形成される。

\section{3. $\mathrm{AC}$ 型 PDP の製造プロセス}

$\mathrm{AC}$ 型 PDP の一般的な製造プロセスは, 図 2, 図 3 に 示すように，前面基板と背面基板をとれぞれ別々に作製 し，組み合わせた後，最終工程を経て完了する。

前面基板は，基板を洗浄後，まず透明導電膜を成膜す る。透明導電膜には, LGD と同様のITO, たは $\mathrm{NESA}\left(\mathrm{SnO}_{2}\right.$ 膜）が用いられる４0インチを越える大 型基板では, 基板両端間距離が $1000 \mathrm{~mm}$ 近くなり, 一 般の透明導電膜のみでは電気抵抗が大きくなり過ぎ，電 


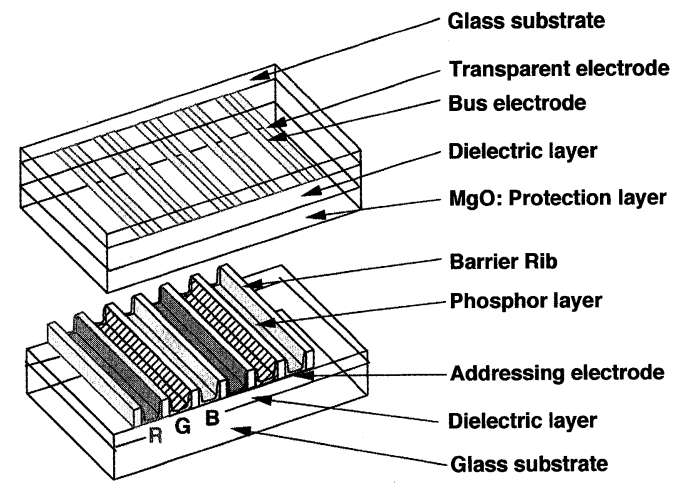

図 1 AC-PDP の構成

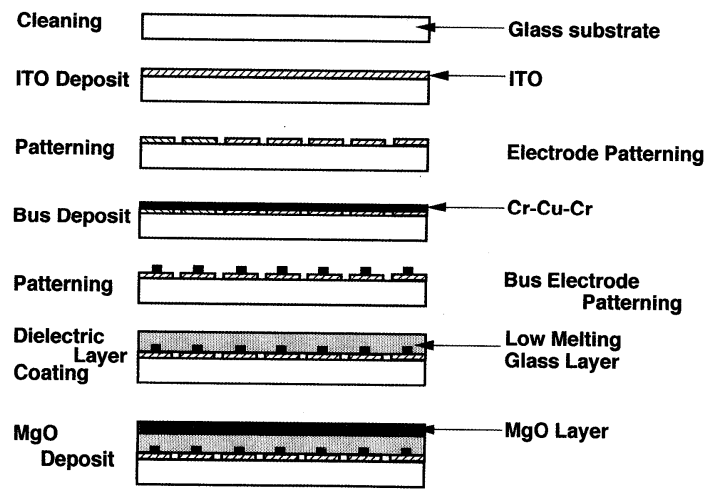

図 2 前面パネルの一般的製造プロセス

圧降下が問題となるため, 図 1,2 に示すバス電極が予 備的に用いられる。バスには，その役割から金属が用い られる, 最も一般的な構成が, 図 1 に示す, $\mathrm{Cr}-\mathrm{Cu}-\mathrm{Cr}$ の 3 層構造である. 透明導電膜, バス電極のパターンニ ング終了後, 放電で生じた電荷を維持するための誘電体 層を形成する. 誘電体層には印刷工程が可能な低融点ガ ラスペーストが用いられる.スクリーン印刷等で電極基 板上·面に塗布後, $500^{\circ} \mathrm{C}$ 程度に加熱し, バインダー成 分を除去し，ガラス成分のみを成膜する. 冷却後, 誘電 体層上に保護膜層が形成する。現行の保護膜層は, $\mathrm{MgO}$ の真空蒸着法が用いられる．前面基板の工程は， 保護膜層の成膜で終了する.

背面基板は，基板を洗浄後，まずアドレス用電極を形 成する. 図 1 亿示す AC 型 PDP では, 背面基板に塗布 した蛍光体からの発光を利用する反射型発光構造である ため，背面基板上の電極は透明体である必要がない，そ のため, $\mathrm{Cr}-\mathrm{Cu}-\mathrm{Cr}$ 等の金属電極, 銀ペーストを主体と

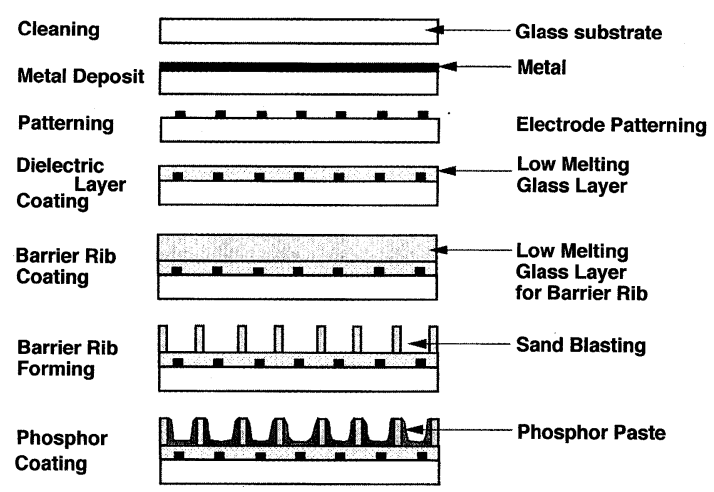

図 3 背面パネルの一般的製造プロセス

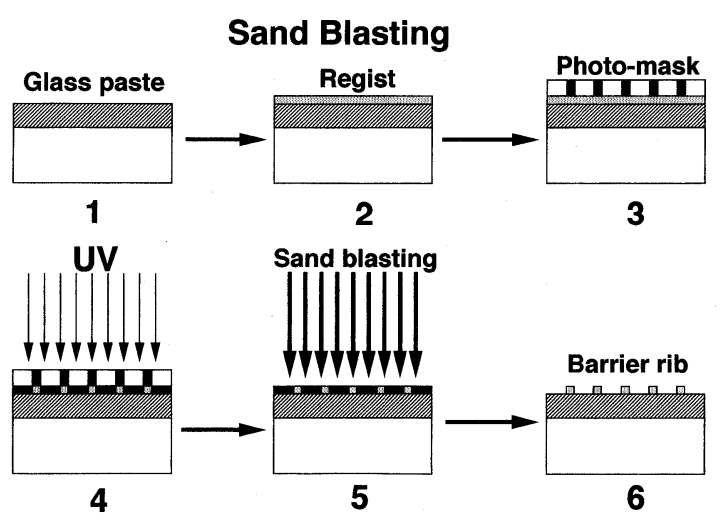

図 4 サンドブラスティングによるバリアリブの作 製

する導電ペースト等により構成される，アドレス用電極 のパターンニング後, 前面基板と同様, 低融点ガラスペ ーストの印刷工程による誘電体層形成が行われる.さら に図 3 に示すとおり, バリヤリブ形成用の低融点ガラス ペースト層が設けられる. バリヤリブの形成は, 幾つか の方法が提案, 実施されているが, 現状で最も一般的な 方法は，サンドブラスティング法である。この方法は， 図 4 に示すように，一様に形成した低融点ガラスペース 卜層上に, 所定のパターンでフォトレジスト層を設け, パターンニング後, 硬質の粒子を吹き付け, 彫り進めて 行く方法である. 他の方法としては, 印刷によりバリヤ リブを形成する方法があるが，一般に $100 \mu \mathrm{m}$ を越える 高さが必要なバリヤリブ層の形成では，10回以上の重称 印刷が必要となり，位置合わせ精度の維持が課題とな る. バリヤリブのパターンニングが終了後, $500^{\circ} \mathrm{C}$ 程度 に加熱し，バインダー成分を除去し，ガラス成分のみを 


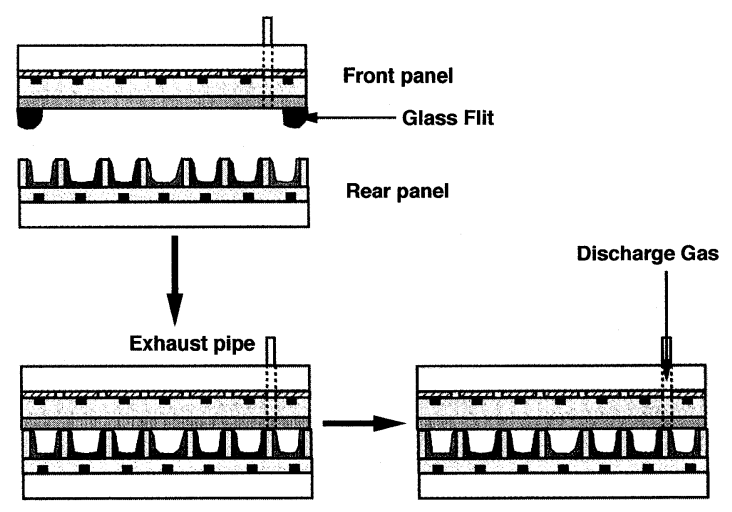

図 5 前面, 背面パネル貼合わせによる最終工程

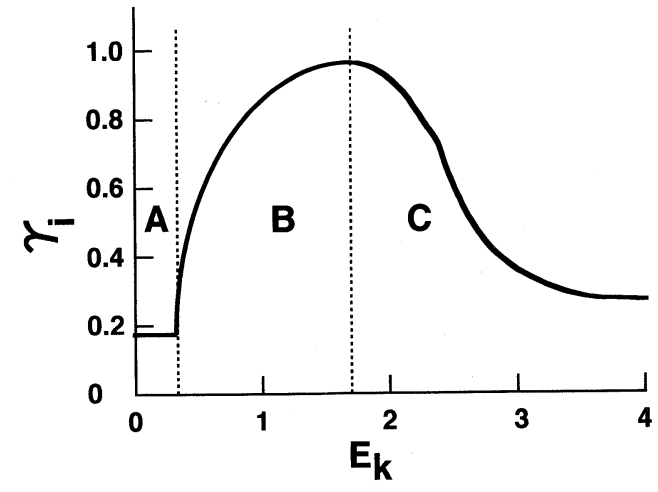

図 6 イオン衝撃による二次電子の放出 入射エネルギーと放出係数の関係
成膜する. 冷却後, 図 3 に示すバリヤリブ層内部に, 蛍 光体を塗布する. 蛍光体の塗布方法にも幾つかあるが, スクリーン印刷法が一般的に行われる。 バインダと混合 した蛍光体ペーストを各色毎に塗布した後, 焼成し, 蛍 光体層を形成する．蛍光体層の形成により，背面基板工 程は終了する.

最終工程として, 前面基板と背面基板を貼り合わせ る.プラズマ放電にさらされるパネル内部のガス環境を 保つため, 貼り合わせにも低融点ガラスペーストが用い られる. 図5に示すと扣り貼り合わせ後, パネル内部の $\mathrm{MgO}$ 表面の活性化, 蛍光体層等のガス出しを行い, 放 電ガスを封入して完成する.

\section{4. 真空成膜の現状と課題}

このように現状の $\mathrm{AC}$ 型 PDP の一般的な製造プロセ スでは, 前面基板, 背面基板の電極形成, 前面基板の保 護膜成膜に真空成膜技術が用いられる．以下，それぞれ の工程に打ける技術的課題について述べる.

\section{1 電極成膜}

PDP では，40インチを越える大画面が標準の基板面 積となるため, 現状では専らスパッタリングが用いられ る. 透明導電膜の技術的要求項目としては, 高い透過 率, 低い電気抵抗, 強い密着強度と, 従来の LCD と同 様であるが，PDP に特有な要求項目として，高い耐熱 性がある。透明導電膜成膜後のプロセスにおける膜の電 気抵抗上昇は，LCDでも課題となっているが，PDPで は，ガラスペーストの焼成工程で $500^{\circ} \mathrm{C}$ を越える温度が 必要となること，执よび40インチを越える極めて長い電 極が必要となることから, 電気抵抗の温度変化低減は重 要な課題である.
一方，透明導電膜成膜後，低融点ガラスペーストを塗 布し，焼成する過程で，技術的課題が残されている．一 般に，金属酸化物である透明導電膜上に，金属酸化物の 混合物で構成される低融点ガラスペーストを接触させ $500^{\circ} \mathrm{C}$ 越える高温にさらすと, 金属酸化物間で固溶相 が形成され，透明導電膜成分が変化してしまら現象が発 生しやすい。この現象は，LCDで一般に用いられる ITOを用いると顕著に発生する. NESA膜は, ITOに 比べ，低融点ガラスペーストとの化学的反応性は低くな るものの本質的には，金属酸化物間での固溶相形成の問 題を回避することは困難である.

根本的に固溶相形成の課題を克服するためには, 低融 点ガラスペーストの焼成温度を $300^{\circ} \mathrm{C}$ 以下にすることが 効果的であるが, 現行の工程では, 全てのプロセスの低 温度化が必要となるため, 今寸ぐ対処することは困難で ある. 現実的に, 課題を克服する方法としては, 透明導 電膜の膜質を改良し，低融点ガラスペーストと高温下で 接触しても実質的に固溶相を形成させないようにするこ とが必要である.このための手法として，真空成膜時の 成膜条件を徹底的に最適化することが考えられる．現状 では，コスト等の要因から, スパッタリングが一般に用 いられているが，表面の膜質を積極的に改良するための 成膜法の研究開発に期待したい.

\section{2 保護層の役割}

$\mathrm{AC}$ 型 PDP を素子構成材料の観点から考喤た時, 最 も重要, かつ成膜条件依存性が顕著に現われるものが, 保護層である。保護層は, 図 1 , 図 2 に構成を図示する と扣り, 低融点ガラスで構成される誘電体層と, 放電ガ スの間に形成される. 他章の放電メカニズムの解説で明 らかなよ5に, 保護層の役割は大きく 2 つに分類され 


\section{Physical Vapor Deposition}

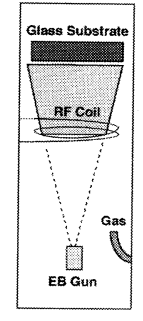

RF lon-Plating
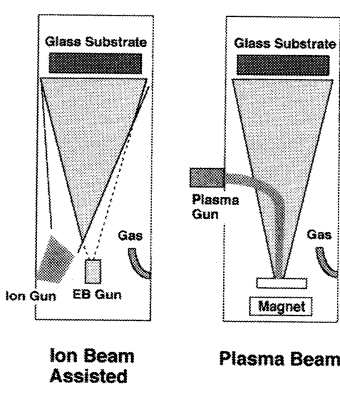

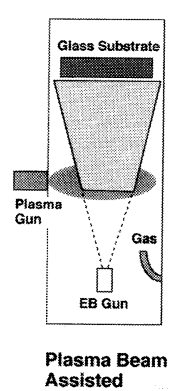

Assisted
図 7 各方式による $\mathrm{MgO}$ の真空成膜

る. 1 つは，放電を開始するための 2 次電子放出機能， 他は, プラズマ放電から誘電体層を保護する機能であ る. 前者は, 放電開始電圧の低減, 要するにできるだけ 低電圧で PDP を駆動するために必要な特性である。後 者は, 放電の安定性, すなわち PDP の寿命を決定する 機能である。

AC 型 PDP は, 励起されたガスがイオン化し，この イオンが保護層に衝突した際に, 保護層から放出される 2 次電子がさらにガスを励起する結果, 真空紫外光を発 生し, この励起光が蛍光体を励起し, フォトルミネッセ ンスにより可視光を発光することで表示が行われる. し たがって，保護層から放出される 2 次電子の数が多い汪 ぞ, 励起ガスからの真空紫外の発光が強いほど, また, 蛍光体のフォトルミネッセンスの発光効率が高いほど, 低電圧で, 高輝度の PDP が得られることになる. 特に 保護層の 2 次電子放出係数は, 放電開始電圧を低減し, 高い発光効率を実現する上で最も重要な要因である.

保護層には, 高い 2 次電子放出係数の汪か, プラズマ 放電にさらされても高い耐久性を持つこと, 蛍光体から の可視光を十分透過する高い透過率を持つこと, 効率良 く成膜でさること等が必要とされる.

前述のと括り, 現状用いられている保護層は, $\mathrm{MgO}$ である. 形成方法としては, 電子ビーム蒸着が最も一般 的である. $\mathrm{MgO}$ は, 比較的高い 2 次電子放出係数を示 し，高融点であるためプラズマ中でも比較的高い耐久性 を示す.さらに, 可視領域に秃いて $90 \%$ 以上の透過率を 持つ. 30 年以上に及ぶ PDP の歴史の中で保護層として の $\mathrm{MgO}$ の出現は比較的早いにも関わらず，現状で $\mathrm{MgO}$ を凌駕する保護層が実用化されていないことは, $\mathrm{MgO}$ の保護層としての資質が極めて高いとともに，今 後, 本格的に新規保護層の探索に乗り出す必要を提起し ている.

$\mathrm{MgO}$ からのイオン励起による2 次電子放出機構につ
いては, Hgstrum ${ }^{1,2)}$, 内池ら ${ }^{3)}$, が詳しい検討を行って いる. 入射イオンのエネルギー（Ek）と，2次電子放出 比 $(\gamma \mathrm{i})$ の間には一般に図 6 に示寸関係があることが知 られている。すなわち，2 次電子放出比（ $(\mathrm{i}$ ) が入射 オンのエネルギー（Ek）に依存しない Potential 領域 (A), Ek 飞依存する Kinetic 領域（B，C）の2つ，さら に Kinetic 領域は, 中間エネルギ一領域（B）と, 高ェ ネルギー領域（C）に分類される. Potential 領域からの 2 次電子放出は, 入射イオンと固体表面の相対的エネル ギー準位により放出比が決まる。一方, Kinetic 領域か らの 2 次電子放出は, 固体と入射イオンの非弾性衝突の 結果として放出比が決定されるものである. Hagstrum ${ }^{1,2)}$ の検討結果では, $\mathrm{MgO}$ からの 2 次電子放 出は, 入射イオンのェネルギー（Ek）飞依存しない Potential 型放出であるが，より実際の PDP に近い系で の内池ら ${ }^{3)}$ の検討によれば，必ずしも Potential 型放出と 断言できないような場合も報告されている.いずれにし ても, $\mathrm{MgO}$ からのイオン励起による 2 次電子放出係数 の測定自体, Hagstrum, 内池らの検討以外, 未だ十分 な報告例がなく、今後の実験的検討が待たれる状況にあ る.

\section{4. $3 \mathrm{MgO}$ 成膜方法と技術的課題}

現行の $\mathrm{MgO}$ 成膜法は, 主として電子ビーム蒸着であ るが，近年のPDP の製品化に呼応する形で新たな成膜 法が次々に提案されている。そ穖つかについて，図７ にまとめた。

$\mathrm{MgO}$ の物性解明については, 前述のと扤り, 未だ検 討が不十分であるが，工業的見地からもう一つの重要な 改善項目としての, 高速成膜に関しては, かなり具体 的, かつ効果的な手法が提案されている.このような成 膜方法として既に大型 PDP 用途として適用可能なもの に Hollow Cathode Discharge（HCD-ARC）を用いた方 法4) $\mathrm{Mg}$ をターゲットとする反応性スパッタリング 法5)就よびプラズマガンを用いたイオンプレーティング 法6をを上げることができる。これらの方法はいずれも， 高速成膜を実現するために金属 $\mathrm{Mg}$ をターゲットとして 用い, 酸素䨌囲気下, 強力な蒸発源で $\mathrm{MgO}$ を成膜しよ らとするものである.40インチを越える大型基板への真 空成膜を, 高い量産性を維持して処理することが課題で あるため, これらの高速成膜法のさらなる技術的発展を 期待したい. 特に, 今後大型 PDP の量産が本格的にな るにつれて，真空成膜装置が巨大化すると，この装置を 設置するためのクリーンルームのスペースが広大なるの となり, ランニングュストも膨大となる。この点から も, 装置の設置面積当たりの処理能力に優れた真空成膜 装置が必要となる. 
しかし，これらの高速成膜法の開発においては， $\mathrm{MgO}$ の膜質管理を徹底的に行らことも忘れてはならな い. 前述の $\mathrm{AC}$ 型 PDP に求められる $\mathrm{MgO}$ の物性は, 一般論としてはかなり明確になってきているものの，成 膜条件と膜物性の相関については，最も実績のある電子 ビーム蒸着でも十分な理解は行われていない状態であ る.

さらに, 真空成膜で得た $\mathrm{MgO}$ 膜は, 大気中の酸素, 水分と容易に化学反応し, $\mathrm{Mg}(\mathrm{OH})_{2}, \mathrm{MgCO}_{3}$ となるこ とが指摘されている. 図2, 図 3 に示す現行の製造プロ セスでは, $\mathrm{MgO}$ 成膜後, 大気中にさらされる機会が発 生するため, 単に成膜時の条件設定だけで, PDP に好 ましい物性を維持することは極めて困難と言わざるを得 ない．大気中に置かれた $\mathrm{MgO}$ の表面，および加熱して 表面を活性状態にした $\mathrm{MgO}$ 表面の AFM による観察結 果が，King ら〕より報告されている，Kingらによる と,（100)配向面を有する $\mathrm{MgO}$ は，アニールにより固 相一固相モデルに従って表面を修復し平坦にしていくこ とが示唆されている.

\section{5. をとめ}

大型 PDP の製造に拈いては, ITO 等の透明電極の成 膜拉よび保護膜用 $\mathrm{MgO}$ の成膜で真空成膜が必要とな る. 現行ブロセスでは, $500^{\circ} \mathrm{Cを}$ 超える高温が必要とな るてめ, ITO 電気抵抗の温度依存性の低減が大さな課 題である. また, 低融点ガラスと接触することに伴う化 学反応を抑制するための ITO 表面状態の解析が必要で ある. 一方, 保護膜用 $\mathrm{MgO}$ には, 二次電子放出係数を 高く, かつプラズマ放電に耐える物性を付与できる成膜
法が求められる。 また，大型 PDPの量産に扮いては， 装置の設置面積当たりの処理能力に優れた真空成膜装置 が不可欠である.

\section{[文献]}

1) Homer D. Hagstrum: "Theory of Auger Ejecton of Electrons from Metals by Ions" Physical Review, 96, No. 2, pp. 336-365 (1954).

2) Homer D.Hagstrum: "Effect of Monolayer Adsorption on the Ejection of Electrons from Metals by Ions", Physical Reviw, 104, No. 6, pp. 1516-1527 (1956).

3）林海, 原野雄一, 内池平樹:「プラズマディス プレイ用保護層材料のイオン衝撃による二次電子放出 特性」テレビジョン学会技術報告 ITE Technical Report, 19, No. 66, pp. 49-54 (1995).

4) M. Hakomori, Y. Hibino, K. Matsuzaki, T. Kurauchi, M. Matsuura and H. Yamakawa: "High Rate Deposition of MgO Film for AC-PDPs by Activated Reactive Evaporation Using Hollow Cathode Discharge (HCD-ARC) "' Proceedings of the fourth International Display Workshops, pp. 551-554, in Nagoya (1997)

5) C. Daube, H. Frankenberger and J. Stollenwerk: "High Rate MgO Sputter Source for PDP Applications" Proceedings of the fourth International Display Workshops, pp. 555-558, in Nagoya (1997).

6) 粟井 清：「新イオンプレーティング法による ITO, $\mathrm{MgO}$ 成膜について」第15回プラズマディスプ レイ技術討論会資料, 講演番号 4 , 名古屋, 1 月 17 日 (1997).

7) Simon L. King, Mark R. Wilby and Ian W. Boyd: "Evolution of the Morphology of Annealed, Bulk MgO (100) Substrate Surface”' J. of Mat. Sci. \& Eng. (B), Paper Presented at EMRS 1995, Strasburg, France (Symposium G) May 1995. 